\title{
Algal Control in Warm Weather Pond Using EMOH Device
}

\author{
Frederick Bloetscher ${ }^{1 *}$, Daniel E. Meeroff ${ }^{1}$, Julia Roblyer ${ }^{1}$, Angela Prymas ${ }^{2}$ \\ ${ }^{1}$ Florida Atlantic University, Boca Raton, USA \\ ${ }^{2}$ City of Boynton Beach, Boynton Beach, USA \\ Email: `h2o_man@bellsouth.net, dmeeroff@fau.edu, jroblyer@fau.edu, PrymasA@bbfl.us
}

How to cite this paper: Bloetscher, F., Meeroff, D.E., Roblyer, J. and Prymas, A. (2018) Algal Control in Warm Weather Pond Using EMOH Device. Journal of Environmental Protection, 9, 882-894. https://doi.org/10.4236/jep.2018.98055

Received: May 8, 2018

Accepted: July 27, 2018

Published: July 30, 2018

Copyright (c) 2018 by authors and Scientific Research Publishing Inc. This work is licensed under the Creative Commons Attribution International License (CC BY 4.0).

http://creativecommons.org/licenses/by/4.0/

(c) (i) Open Access

\begin{abstract}
Nuisance algal blooms have been a topic of discussion in Florida as a result of highly visible adverse impacts to coastal waters, but algae is hardly a new concern for warm weather communities. The typical treatment is with copper sulfate. However, copper has been identified by regulatory agencies as a contaminant of concern in coastal waters and has been targeted for stricter regulations, potentially limiting its use in the future for algae control. The $\mathrm{EMOH}$ device was proposed as a means to test whether a "green" solution could be found to this algae concern. EMOH creates high volume oxidation in concert with activated organisms. The initial treatment effort covered one year (2016). During treatment, water quality was monitored with periodic measurements of the benthic detrital layer, which is a precursor to algal blooms in these ponds. Photographs of the extent of algal coverage on the surface, water quality in the pond and thickness measurements of the detrital layer defined success. Through the hot summer, despite regular influx of nutrients and rain, the amount of algae declined, and the detrital layer decreased in thickness from $22-24$ inches to $7-8$ inches. The decrease of the detrital layer means that over time, the benthic source of nutrient availability can be more controlled. The authors concluded that the EMOH process was successful and that physically removing the detrital layer may be an important step in long-term algal reductions.
\end{abstract}

\section{Keywords}

Algae Blooms, Oxidation, Reduced Detrital Mats

\section{Introduction}

Florida has experienced major cyanobacterial algaebloom episodes along both coasts in recent years, primarily caused by large releases of nutrient-laden lake 
water to the ocean for flood control. This has not always been the case, because the nutrient limited environment throughout the state prevented major algal outbreaks. However, as a result of terrestrial changes that began over 100 years ago, algal blooms have become a constant concern for communities throughout the state. A little history helps explain how these changes manifest themselves with algae.

In 1904, Napoleon Bonaparte Broward campaigned to drain the Everglades swamp for farming and real estate. Broward's efforts initiated the first land boom in Florida, although it was interrupted in the 1920s by hurricanes (1926 and 1928) that sloshed water out of Lake Okeechobee causing severe property damage and loss of life in Miami and around Lake Okeechobee. To prevent recurrence, the existing earthen dike that was breached by the hurricanes in the 1920s was replaced by a larger system of 143 miles of levees came to be known as the Herbert Hoover Dike (HHD). Canals were designed to move water from agricultural property to the lake.

In the late 1940s, hurricanes again hit Florida, causing damage and flooding from Lake Okeechobee, prompting Congress to direct the Army Corps of Engineers to build 1800 miles of additional canals, dozens of pump stations and other structures to drain the area south of Lake Okeechobee. Collectively, these projects lowered the groundwater table, allowing more land for farming and development. The use of fertilizers increased. 470,000 acres of the Everglades was set aside for farming on the south side of Lake Okeechobee and designated as the Everglades Agricultural Area (EAA). Farming activities began around the lake as a result, but while the organic content of the peat soil was high, the nutrient quality was poor, so massive amounts of fertilizers were introduced. Irrigation in the EAA is fed by a series of canals through which water is pumped in or out depending on the needs of the predominant crops. Back-pumping to Lake Okeechobee and pumping to the water conservation areas were practices used to address flooding issues, but as was discovered later, the water made significant changes to the local ecosystem, and the runoff enriched coastal water nutrient concentrations with its low dissolved oxygen and high levels of nitrogen and phosphorus.

There was an initial benefit to Lake Okeechobee receiving elevated nutrients. In the 1980s, the lake became a prime source for catching lunker bass. The change was caused by back-pumping of high nutrient waters, which stimulated productivity and led to more biota and larger fish. This worked as long as the system was in balance-i.e. nutrients need to be growth limiting at the lower end of the food chain. However, cumulative inputs led to runaway nutrient loading that stimulated eutrophication. Today, Lake Okeechobee is overwhelmed with algae. Lunker bass disappeared over 20 years ago, and prolonged back-pumping has led to dead zones in the lake, which triggers algal progressions, leading to toxic blue-green algae blooms thatthreaten drinking water supplies from Lake Okeechobee and the downstream Everglades. Every community in south Florida today is a microcosm of Lake Okeechobee-full of nutrients, warm, and subject 
to ongoing algal blooms.

The City of Boynton Beach is located between the southeast Florida coastal communities of Delray Beach and Lake Worth, just south of West Palm Beach. The City treats has numerous ponds that they control. These ponds create neighborhood complaints due to frequent algal blooms. These ponds are treated with copper (II) sulfate.

Within the City has a wealthy area called the Intracoastal Neighborhood Community Association. Within the community are 4 ponds, deemed the INCA ponds, that create neighborhood complaints due to frequent algal blooms caused by the introduction of nutrients from runoff from the nearby residential community. All four are typical of southern waters, characterized as being slow moving and warm, which encourages cyanobacteria-or blue green algae [1]. The ponds are connected to the Intracoastal Waterway and the local drainage system. The discharges are in proximity to protected mangroves in the Lake Worth Lagoon.

The City of Boynton Beach maintains these high-profile sites in the priorities inspection/maintenance list. The ponds are inspected sometimes several times a week due to neighbors' complaints, and historically copper (II) sulfate has been added to control algal mats on the surface. A number of operational issues have been identified, including but not limited to:

- Loss of vegetation in the littoral zone and minimal embankment erosion;

- Introduction of fresh water runoff into a brackish ecosystem;

- Water murkiness and odor;

- Barnacle growth around fountain plumbing;

- Fountain electrical mechanism not working consistently;

- Mosquitos on the ponds, etc.

Previous attempts to manage algal overgrowth by the City of Boynton Beach Utilities Department have included the use of chemical algaecides and manual removal of algae. These options have proven to be only temporary solutions soon followed by rapid regrowth and deposition of detrital matter of the bottom of the ponds. Copper (II) sulfate kills the algae, which then settles to the bottom, increasing the stored nutrients in the benthic detrital layer. It was noted that the pond had a thick layers of debris on the bottom of the pond. Samples of the debris layer in the pond indicated that the layer was comprised mainly of organic matter (dead algae). The organic fraction contained the material necessary for accelerated algae production during the warmer months of the year. Appreciable amounts of detrital matter can encourage the growth or regrowth of bacteria on the bottom. Meeroff et al. [2] noted this during a study of coastal Taylor County, FL before and after septic tanks were replaced by a sewer network. Carsey et al. [3] also identified the regrowth issue as a problem with the Lake Worth Lagoon, which abuts and is connected to the INCA ponds.

Compounding the issue was that the estuarine habitats and wetlands of Lake Worth Lagoon, the largest estuary in Palm Beach County, was restored in 2009 
by installing limestone boulder riprap material along the shoreline with mangrove planters behind them to combat erosion caused by wind and boat wake activity [4].

Therefore, the Citysought a more sustainable solution. The Electromagnetic Oxygen/Hydrogen (EMOH) device was previously tested for treating leachate [5] [6] [7] [8]. In these experiments, the researchers demonstrated that the EMOH device could reduce TOC by $75 \%$ in a short period of time. Lakner [4] also demonstrated that the device entrained high concentrations of oxygen, which created an oxygen supersaturation condition. It was suggested that the EMOH process, along with introduced bacteria, would decrease benthic nutrients from prior copper (II) sulfate treatments, thereby reducing the bioavailable nutrients in the water column and eliminating the use of copper sulfate. $\mathrm{EMOH}$ is a static device that inserts atmospheric oxygen into the water stream bringing the dissolved oxygen levels to saturation [6]. The primary activity is to increase the oxygen levels of the water through mechanical means. The purpose of high amounts of oxygen is to ensure that the water is able to exist in an aerobic condition and prevent the formation of algae and other contaminants. The reactor induces electrolysis of the water molecules to separate hydrogen and oxygen. The correct input of electrical charge is needed to provide full enthalpy of the $\mathrm{H}_{2}-\mathrm{O}_{2}$ products. The objective of the pilot study was to evaluate the $\mathrm{EMOH}$ process as an alternative for the City to resolve water quality concerns in the INCA Ponds, and possibly in other stormwater ponds within the City.

\section{Methodology}

As part of a small-scale pilot study, the City of Boynton Beach Utilities Department, in partnership with Florida Atlantic University, installed an Electromagnetic Oxygen/Hydrogen (EMOH) reactor in INCA Pond Site 3 (located on the southeast corner of NE $8^{\text {th }}$ Ave and NE $7^{\text {th }}$ St, Boynton Beach, FL 33435), in place of a fountain that existed previously. Concurrently the process requires the use of microbial-based probiotics to accelerate cleanup in the initial stage. The pond was originally treated with CBX Optimizer and CBX Sniper along with EMOH daily treatment. The CBX Sniper was added weekly, then bi-weekly after 3 months based on the pond condition, at the rate of 6 gallons/90 days. The suggested application rate is 30 gallons per acre per year from the manufacturer (given the pond size, the dose was adjusted accordingly).

To better understand the water conditions of the pond, mechanisms that may control algal growth and whether the EMOH reactor might be beneficial to water quality, various in situ and laboratory water quality measurements were conducted from the beginning of May 2016 through the end of 2016, including both Florida's summer and wet seasons. Dissolved oxygen levels were monitored using a YSI556 MPS probe to determine whether harmful hypoxic conditions had developed in the pond due to macroalgae proliferation. If conditions were not hypoxic, the absence may be attributable to the EMOH reactor, since algal 
proliferation due to eutrophication is usually concurrent with hypoxia. As a means to measure success, providing aesthetic improvements in this neighborhood increasing resident's satisfaction and decreasing numbers of complaints were monitored along with water quality parameters. Also, the thickness of the detrital layer was measured periodically by wading into the pond an measuring the depth of the detrital layer because it was suggested that this layer holds nutrients and contributes to algal regrowth.

\section{Water Quality}

Florida Atlantic University conducted water sampling. The list of testing parameters included:

- Dissolved Oxygen (mg/L and percent saturation)

- Temperature $\left({ }^{\circ} \mathrm{C}\right)$

- Pressure (in-Hg)

- $\mathrm{pH}$

- ORP (mV)

- Conductivity (mV)

- Specific Conductance $(\mathrm{mS} / \mathrm{cm})$

- Salinity (PSU)

- $\operatorname{TDS}(\mathrm{mg} / \mathrm{L})$

All of these water quality parameters were analyzed using Standard Methods [9]. Measurements for DO (mg/L), DO Saturation (\%), $\mathrm{pH}$, temperature and pressure were collected in the field using a $\mathrm{HACH} \mathrm{HQ} 40 \mathrm{~d}$ multi-meter combined with an LDO probe and a $\mathrm{pH}$ probe, calibrated in the laboratory twice weekly to ensure proper functioning.

Pond water samples from INCA Pond Site 3 were taken a maximum of once per day. If it had rained proximal to the time of field measurement, a decision was made not to take readings because the introduction of rainfall and runoff into the pond would have skewed the results. Samples were taken using a sample bottle attached to a pole. The sample bottle was rinsed in the pond water three times prior to collecting the sample. Samples were taken from the approximate left, right and center of the pond, $6-12$ inches below the surface to allow a broader representation of conditions. Data from the three sampling areas was averaged per day before data analysis.

Water level data was obtained from the National Oceanic and Atmospheric Administration (NOAA) Center for Operational Oceanographic Products and Services (CO-OPS), which provides tidal and water level data, among other metrics. Data was collected from the Tsunami Capable Tide Station at Lake Worth Pier (8722670), approximately 6.6 miles north and east of the INCA Pond Site 3.

The thickness of the detrital mat was measured by EMOH staff with the help of City staff by entering the pond and using measuring stick. A series of statistical analyses were conducted using XLStat, an Excel ${ }^{\circ}$ add-on package to evaluate potential relationships between variables. 


\section{Results and Discussion}

According to the USEPA, DO concentrations should not fall below $5 \mathrm{mg} / \mathrm{L}$ to maintain healthy water bodies in terms of sustaining aerobic life [10]. The reference threshold of hypoxia is $2 \mathrm{mg}$ of $\mathrm{O}_{2} / \mathrm{L}$ [11] [12]. Since the pond showed visual signs of being eutrophic, as substantiated by profuse algal proliferation, levels of dissolved oxygen at or above $5 \mathrm{mg} / \mathrm{L}$ were expected to be unusual. However, the pond had only one instance of hypoxic levels of oxygen $(<2 \mathrm{mg} / \mathrm{L})$, on the very first day of data collection. There were nine instances when the DO fell below $5 \mathrm{mg} / \mathrm{L}$. Since the majority of tests indicated the DO was well above 5 $\mathrm{mg} / \mathrm{L}$, the conclusion was that the $\mathrm{EMOH}$ reactor is preventing hypoxia in the pond despite eutrophication. Keeping the pond in an aerobic condition would counteract the prior complaints related to anaerobic conditions: foul odors and the death of aerobic organisms.

Contrary to the hypothesis that ocean water levels may have a significant effect on the dissolved oxygen of the pond, there was no significant relationship observed, although the water temperatures were fairly constant from day-to-day regardless of the water quality. There were statistically significant correlations with the water quality data collected. The strongest relationships between all in situ measurements were:

- Scatter plot of DO with $\mathrm{pH}$. The plot indicates a clear positive correlation between the two variables (Figure 1).

- Scatter plot of DO with conductivity reveals a negative correlation (Figure 2). This is not unexpected because $\mathrm{DO}_{\text {sat }}$ is a factor of temperature, elevation, and salinity (conductivity, TDS).

- Scatter plot of DO with DO saturation reveals a very strong positive correlation which was expected as well.

Table 1 outlines the summary statistics from XLStat ${ }^{\oplus}$, which shows that the temperatures were warm when the data was collected. Table 2 is the correlation matrixfrom XLStat showing statistically significant correlations were found between:

Table 1. Summary statistics for Water quality samples.

\begin{tabular}{cccccc}
\hline Variable & Units & Minimum & Maximum & Mean & Standard deviation \\
\hline $\mathrm{pH}$ & Standard units & 7.30 & 7.80 & 7.54 & 0.13 \\
Temperature & ${ }^{\circ} \mathrm{C}$ & 26.4 & 32.8 & 30.5 & 1.56 \\
Conductivity & $\mathrm{mV}$ & -71.500 & -39.200 & -57.890 & 7.717 \\
DO & $\mathrm{mg} / \mathrm{L}$ as $\mathrm{O}_{2}$ & 1.70 & 11.4 & 6.62 & 2.48 \\
DO Saturation & $\%$ & 22.20 & 158.70 & 89.25 & 33.73 \\
Pressure & in & 1005 & 1014 & 1009 & 2.2 \\
Water Level & $\mathrm{ft}$ & -0.180 & 1.010 & 0.476 & 0.367 \\
Tide & $\mathrm{ft}$ & -0.617 & 2.927 & 1.583 & 1.085 \\
\hline
\end{tabular}


Table 2. Correlation matrix.

\begin{tabular}{ccccccccc}
\hline Variables & $\begin{array}{c}\text { Avg } \\
\mathrm{pH}\end{array}$ & $\begin{array}{c}\text { Avg } \\
\text { Temp }\end{array}$ & $\begin{array}{c}\text { Avg } \\
\text { Conductivity }\end{array}$ & Avg DO & $\begin{array}{c}\text { Avg DO } \\
\text { Saturation }\end{array}$ & $\begin{array}{c}\text { Avg } \\
\text { Pressure }\end{array}$ & $\begin{array}{c}\text { Water } \\
\text { Level }\end{array}$ & Tide \\
\hline Avg pH & $\mathbf{1}$ & $\mathbf{0 . 3 7 6}$ & $-\mathbf{0 . 9 3 1}$ & $\mathbf{0 . 7 8 5}$ & $\mathbf{0 . 8 0 3}$ & 0.060 & 0.067 & 0.074 \\
Avg Temp & $\mathbf{0 . 3 7 6}$ & $\mathbf{1}$ & -0.292 & 0.260 & 0.276 & 0.101 & -0.304 & -0.180 \\
$\begin{array}{c}\text { Avg } \\
\text { Conductivity }\end{array}$ & $-\mathbf{0 . 9 3 1}$ & -0.292 & $\mathbf{1}$ & $-\mathbf{0 . 8 4 1}$ & $-\mathbf{0 . 8 5 0}$ & -0.100 & -0.019 & 0.015 \\
Avg DO & $\mathbf{0 . 7 8 5}$ & 0.260 & $-\mathbf{0 . 8 4 1}$ & $\mathbf{1}$ & $\mathbf{0 . 9 9 8}$ & 0.228 & 0.113 & 0.104 \\
Avg DO & $\mathbf{0 . 8 0 3}$ & 0.276 & $-\mathbf{0 . 8 5 0}$ & $\mathbf{0 . 9 9 8}$ & $\mathbf{1}$ & 0.213 & 0.100 & 0.093 \\
Saturation & & & & & & & & \\
Avg Pressure & 0.060 & 0.101 & -0.100 & 0.228 & 0.213 & $\mathbf{1}$ & 0.134 & 0.141 \\
$\begin{array}{c}\text { Water Level } \\
\text { Tide }\end{array}$ & 0.067 & -0.304 & -0.019 & 0.113 & 0.100 & 0.134 & $\mathbf{1}$ & $\mathbf{0 . 8 1 4}$ \\
\hline
\end{tabular}

Values in bold are different from 0 with a significance level alpha $=0.05$.

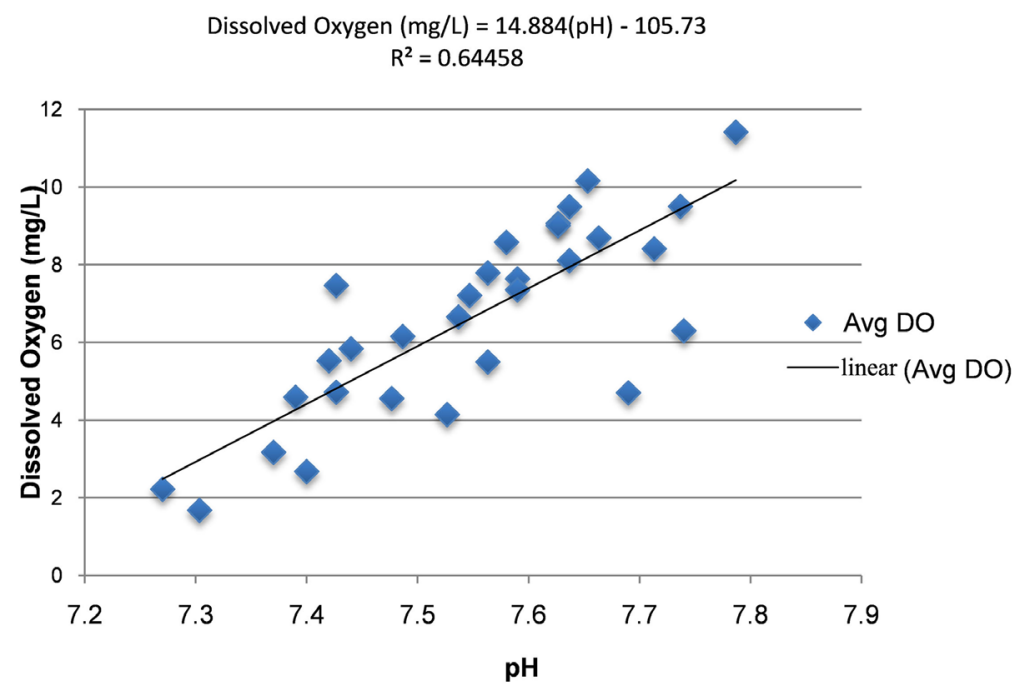

Figure 1. Scatter plot of DO with $\mathrm{pH}$. The plot indicates a clear positive correlation between the two variables.

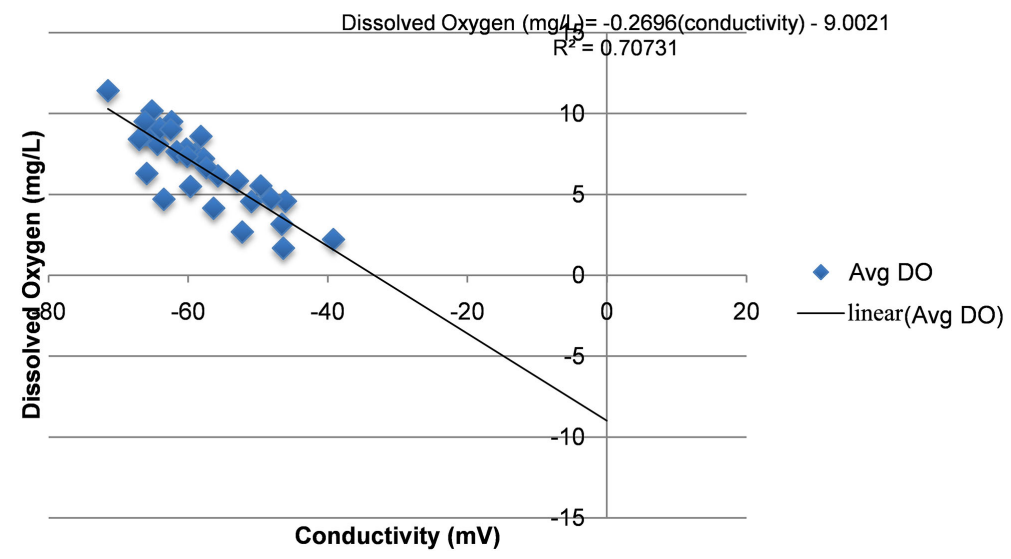

Figure 2. Scatter plot of DO with conductivity reveals a negative correlation. 
- Temperature and $\mathrm{pH}$

- DO and DO saturation and $\mathrm{pH}$

- Conductivity and $\mathrm{pH}$ (strongly negative)

- Conductivity and DO (strongly negative)

- Tides and water levels

The negative conductivity correlations with $\mathrm{DO}$ and $\mathrm{pH}$ were not unexpected. Seawater tends to have lower DO values [13]. Hence as conductivity climbed, the $\mathrm{DO}$ and DO saturation decrease. As the conductivity increased, the $\mathrm{pH}$ dropped. This is also not surprising because it indicates an influx of Lagoon water, which has a lower $\mathrm{pH}$ than the INCA ponds. It is the correlation that should be studied further for nutrients and chlorophyll $\alpha$.

In conducting a principle component analysis, Figure 3 shows that the water quality parameters grouped as a factor (conductivity negatively) and water levels grouped as a separate factor. Pressure and temperature do not seem to be large impacts on either factor. The use of linear regression analysis indicated that only conductivity really drove DO (see Figure 4).

Visual observation showed that the pond began with significant algal surface coverage, which was expected to worsen with the warmth of the summer. The tidal action also flushed out the CBX Sniper additive, requiring periodic replacement. It should be noted that in July, the research group tried a new formulation of microbes that were reported to specifically eliminate the algae. These products did not have the response advertised to the team changed back to strictly using the CBX Sniper. Despite the interruption of additives, Figure 5 and Figure 6 show clearing despite being warm summer months. Nutrients are

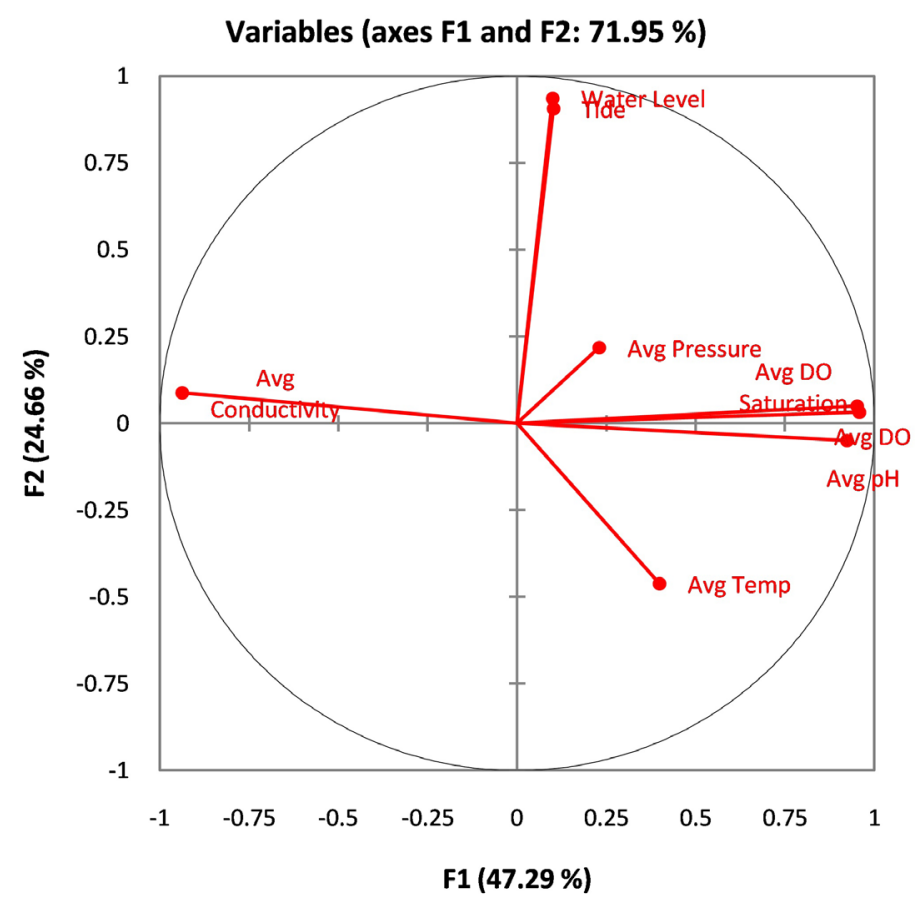

Figure 3. Varimax plot that indicates that $\mathrm{DO}, \mathrm{DO}$ saturation and $\mathrm{pH}$ were strongly related, and strongly unrelated to conductivity in Factors 1 and 2. 


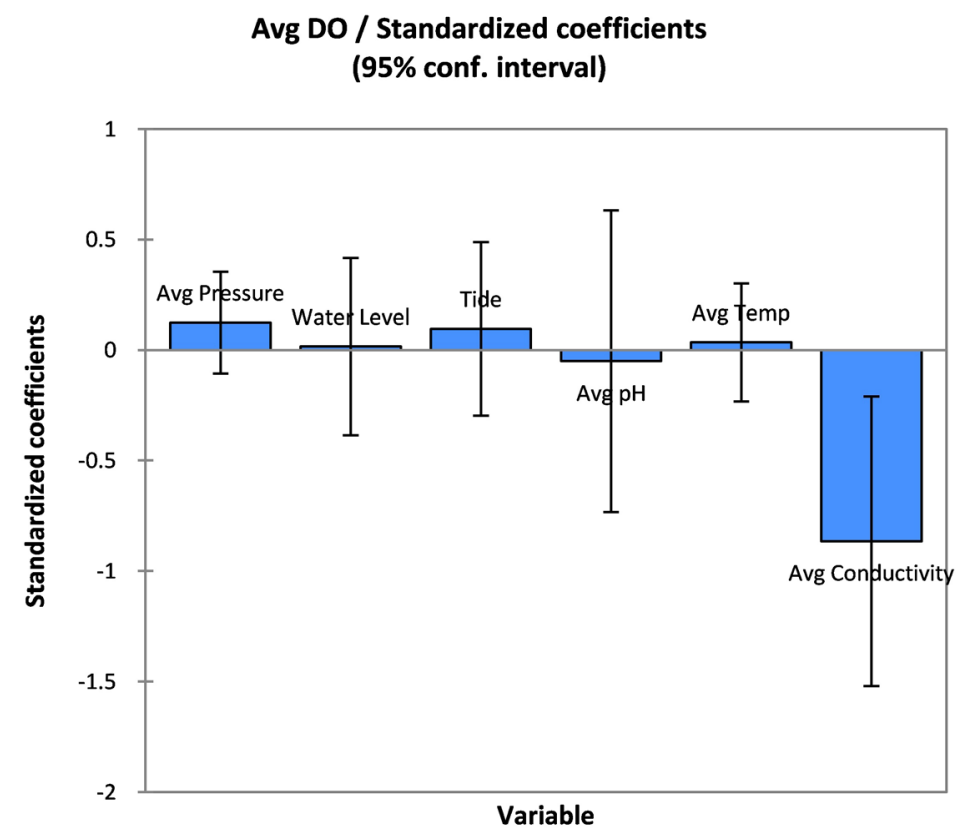

Figure 4. Datacontribution to linear regression model.

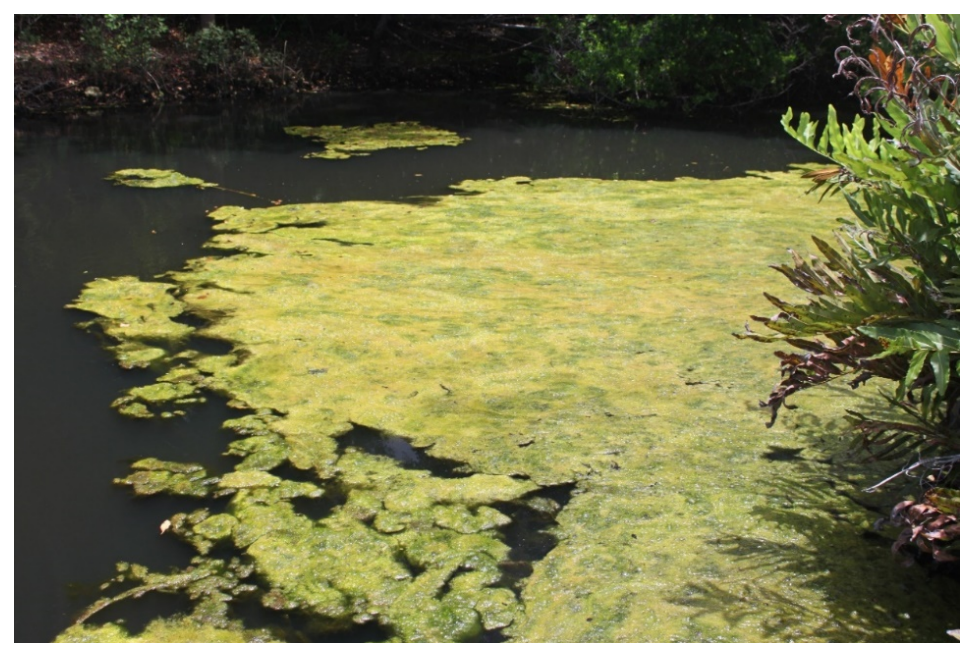

Figure 5. June 20, 2016.

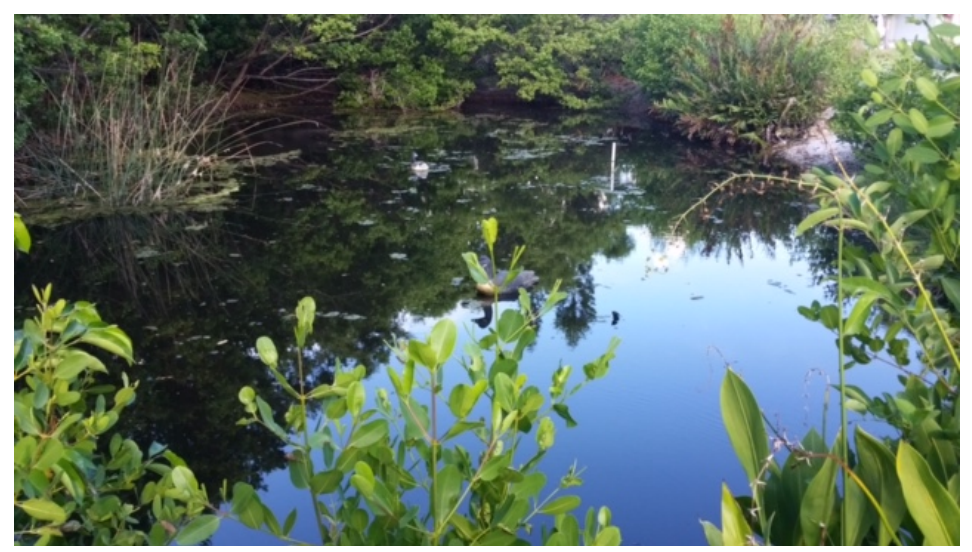

Figure 6. July 14, 2016. 
known to be in the Lake Worth Lagoon from prior study by FAU and NOAA [3]. In addition, the dissolved oxygen levels did not decrease as would be expected during the summer months. The algae cleared in the fall, as temperatures decreased, in contrast to surrounding ponds.

Table 3 shows that despite the fact that nutrients could flow into the pond, the depth of the detrital layer decreased, and visual surveys indicated that the bottom became more visible with time. Figures 7-10 show that the depth of the sludge layer decreased from 24 inches at its initial maximum to less than $6-8$ inches. This is an indication that the EMOH device reduced the organics and nutrients on the bottom needed for the algae to grow rapidly.

Table 3. Sludge depth in the pond (inches).

\begin{tabular}{ccccc}
\hline Site on Figure -10 & April 2016 & August 2016 & Sept 2016 & Feb 2017 \\
\hline 1 & 24 & 24 & 21 & 7 \\
2 & & 21 & 16 & 9 \\
3 & 20 & 20 & 16 & 9 \\
4 & & 20 & 14 & 8 \\
5 & 19 & 14 & 8 \\
6 & 18 & 13 & 0 \\
\hline
\end{tabular}

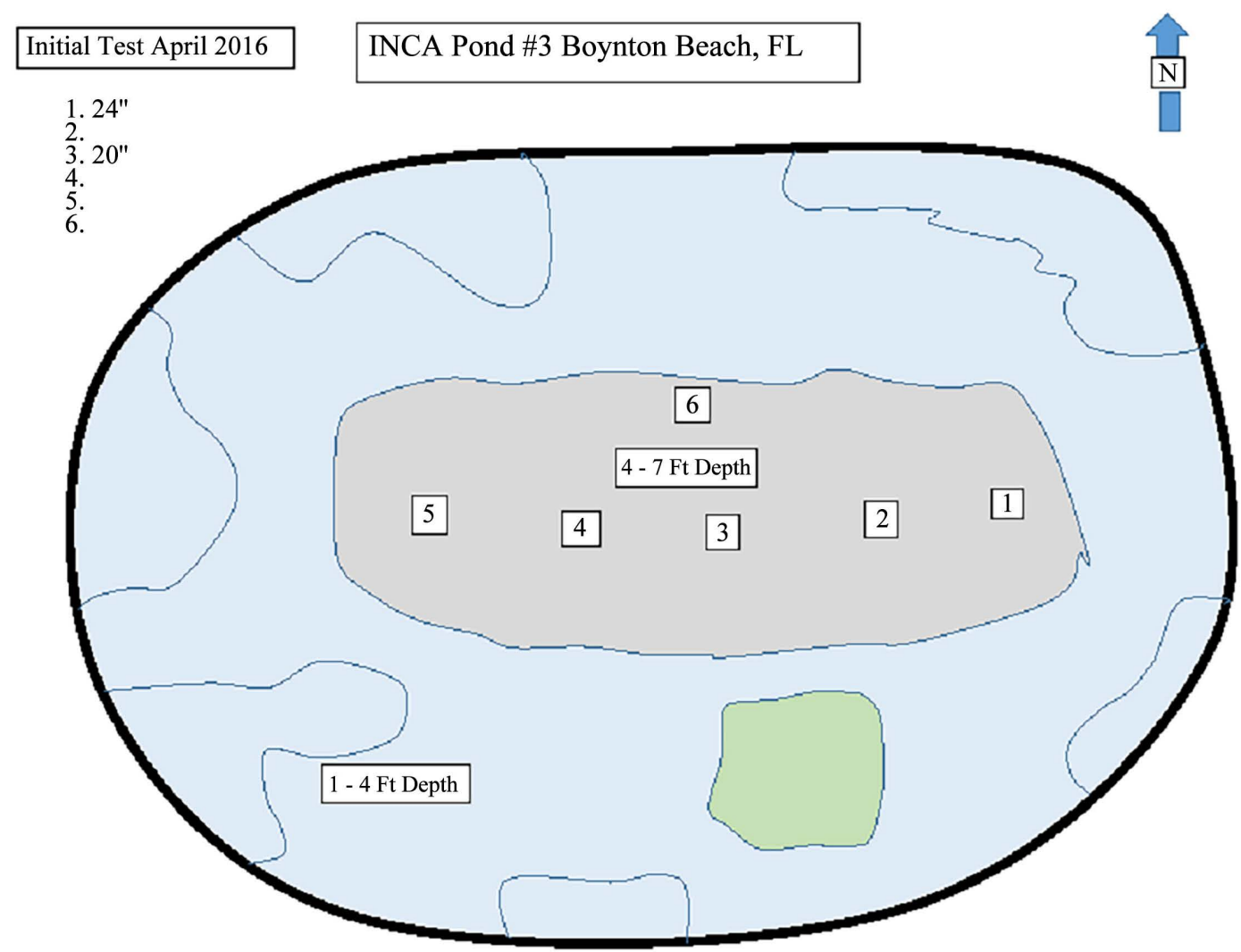

Figure 7. April pond diagram and sampling locations. 


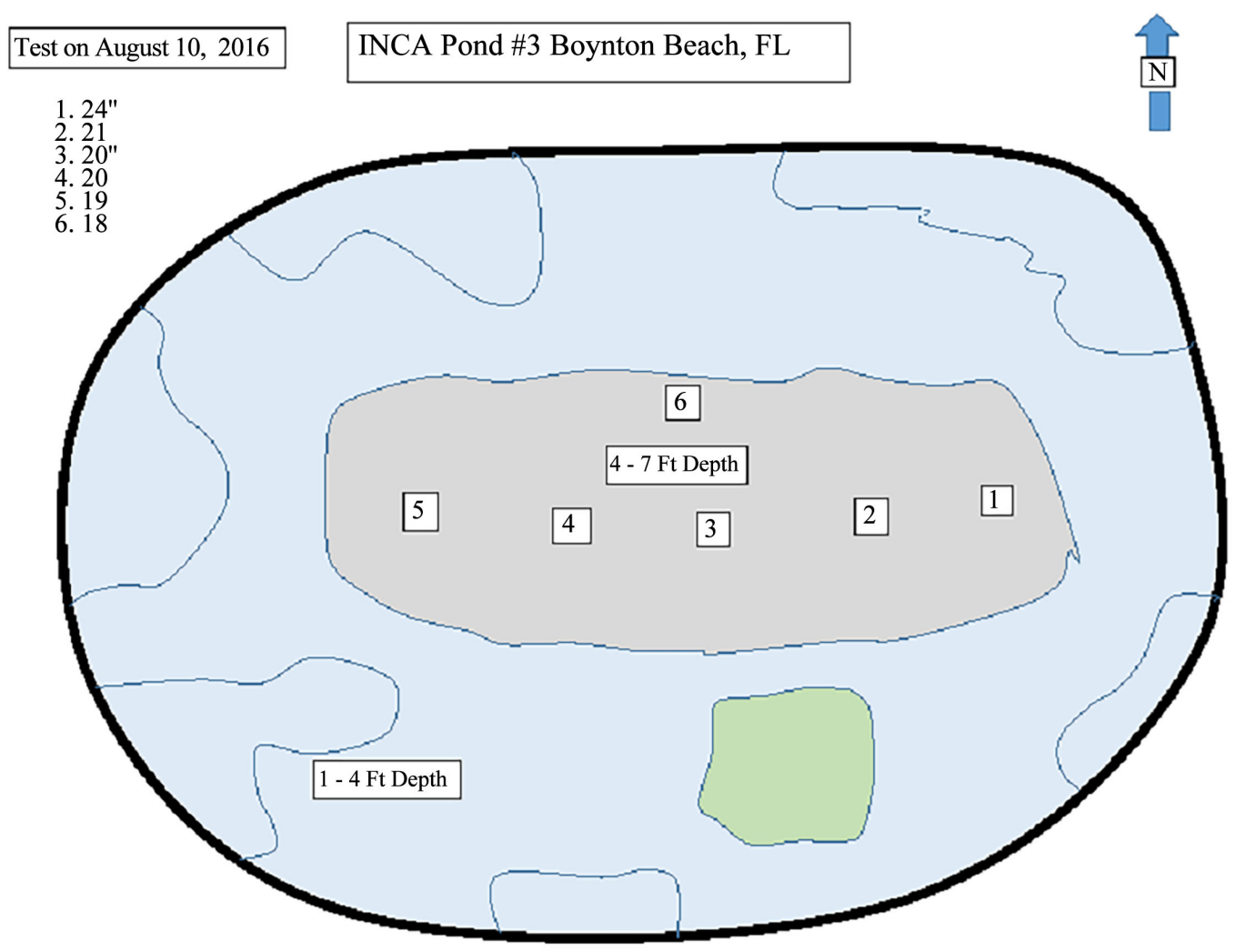

Figure 8. August pond diagram and sampling locations.

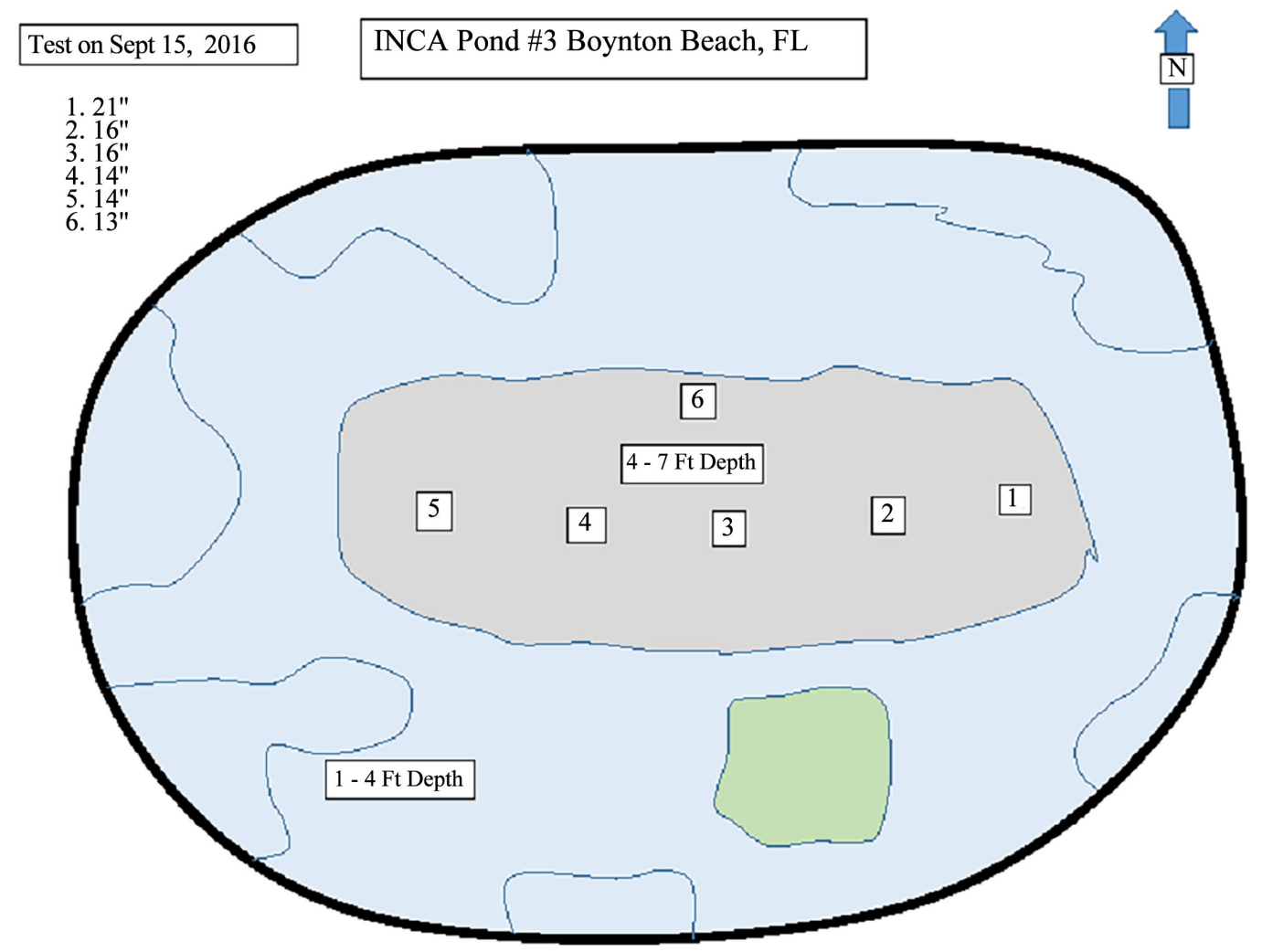

Figure 9. September pond diagram and sampling locations. 


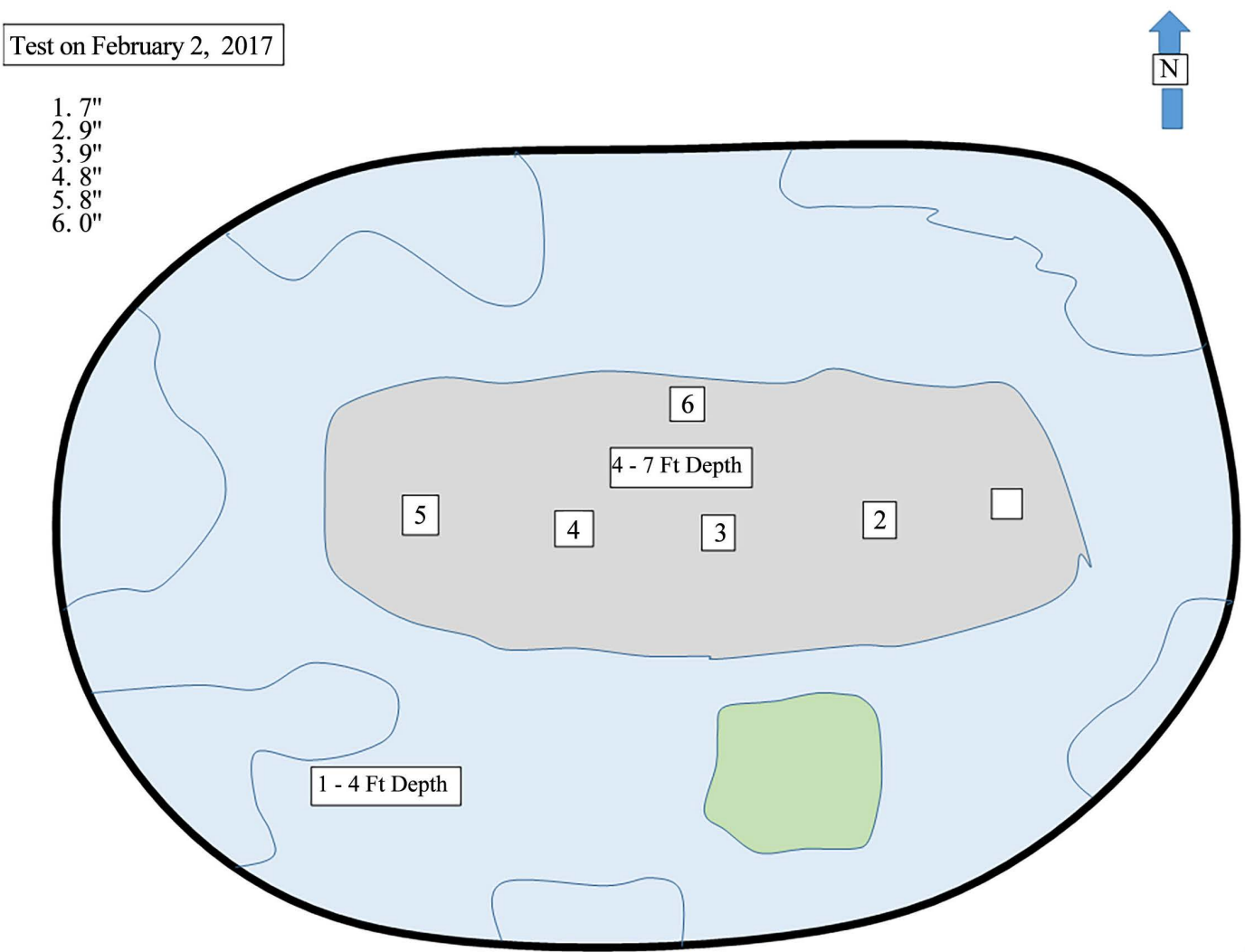

Figure 10. February 2, 2017 pond diagram and sampling locations.

\section{Conclusions}

The City of Boynton Beach is currently treating algal blooms with copper (II) sulfate, but the City is looking for a more sustainable solution to resolve algal complaints because the copper can migrate into the Lake Worth Lagoon, and copper has been identified as a potential contaminant to regulate in the lagoon. The INCA ponds are among the more problematic water bodies in the City with respect to algae. An EMOH device was installed in INCA pond \#3 and was successful at maintaining the dissolved oxygen levels high-in most cases it exceeded saturation and was rarely under $5 \mathrm{mg} / \mathrm{L}$ despite high water temperatures $\left(>25^{\circ} \mathrm{C}\right)$. The detrital mat on the bottom of the pond gradually reduced over a 9-month period. Tidal activity did wash the microbial additives out of the pond, requiring periodic reseeding. Over the summer, the timing for re-seed was determined to be monthly. Given the successful implementation of the process at INCA Pond \#3, future pond restoration sites with sludge mats should start treatment in the winter months to allow the bacteria to consume the mats to decrease the amount of available nutrients that feed the algal blooms.

A follow-up project should be undertaken to compare another INCA pond to INCA Pond 3. The follow-up project should be designed to increase water quality comparisons through the summer months. Data on bacteria, organics and chlorophyll $\alpha$ would be beneficial to the follow-up project. 


\section{References}

[1] USEPA (2007) National Management Measures to Control Nonpoint Source Pollution from Hydromodification. USEPA, Washington DC. http://www.epa.gov/owow/nps/hydromod/index.htm

[2] Meeroff, D.E., Bloetscher, F. and Bocca, T. (2008) Evaluation of Water Quality Impacts of On-Site Treatment and Disposal Systems on Urban Coastal Waters. Air, Water and Soil Pollution, 192, 11-24. https://doi.org/10.1007/s11270-008-9630-2

[3] Thomas, C., Stamates, J., Zhang, J.-Z., Bloetscher, F., Meeroff, D., Amornthammarong, N., Bishop, J., Brown, C., Featherstone, C. and Proni, J. (2015) Point Source Nutrient Fluxes from an Urban Coast: The Boynton (Florida). Environment and Natural Resources Research, 5, 121.

[4] Palm Beach County Board of County Commissioners Department of Environmental Resources Management (2009) Boynton Beach/Ocean Ridge Mangrove Riprap: A Lake Worth Lagoon Restoration Project.

[5] Lakner, J. (2015) Safe Discharge of Landfill Leachate to the Environment. Thesis, Florida Atlantic University, Boca Raton.

[6] Meeroff, D.E. (2016) Futuristic On-Site Leachate Management. EWRI Conference Submission. https://doi.org/10.1061/9780784479865.001

[7] Meeroff, D.E., Lakner, J., Shaha, B., Walecki, E., Harris, A. and Meyer, L. (2016a) Futuristic On-Site Leachate Management. World Environmental and Water Resources Congress 2016, 1-10. https://doi.org/10.1061/9780784479865.001

[8] Meeroff, D.E., Lakner, J. and Coffman, N. (2016b) Safe Discharge of Landfill Leachate to the Environment Year 2 Final Report.

[9] APHA/AWWA/WEF (2017) Standard Methods for the Examination of Water and Wastewater. 23rd Edition, American Public Health Association, American Water Works Association, Water Environment Federation, Denver.

[10] United States Environmental Protection Agency (2002) National Recommended Water Quality Criteria (Vols. EPA-822-R-02-047). United States Environmental Protection Agency, Washington DC.

[11] Best, M.W. (2007) Dissolved Oxygen as a Physico-Chemical Supporting Element in the Water Framework Directive (Vol. 55). Marine Pollution Bulletin.

[12] Shen, J.W. (2008) Hypoxia in a Coastal Embayment of the Chesapeake Bay: A Model Diagnostic Study of Oxygen Dynamics (Vol. 31). Estuaries and Coasts.

[13] APEC Water, 2017. https://www.freedrinkingwater.com/water_quality/water-science/j-9-08-does-salt-c oncentration-salinity-water-affect-solubility-oxygen-page2.htm 